\title{
Moral and Spiritual Self-Improvement of Russian Youth in the Context of Religious and Cultural Awareness
}

\section{La superación moral y espiritual de la juventud rusa en el contexto de la conciencia religiosa y cultural}

\author{
Flera Gabdulbarovna Mukhametzyanova \\ Doctor of Pedagogical Sciences, Professor, Department of Historical and Civic Education, \\ Institute of International Relations of Kazan (Volga Region) Federal University, Russia \\ ORCID: http://orcid.org/0000-0001-9991-1549 \\ Irina Petrovna Krasnoshchechenko \\ Doctor of Psychological Sciences, Associate Professor, Professor of Social and Organizational \\ Psychology, Head of the Centre for Social and Psychological Research and Counselling, \\ Psychology Institute, K.E. Tsiolkovsky State University of Kaluga, Russia \\ ORCID: http://orcid.org/0000-0002-8274-960X \\ Anastasia Victorovna Fakhrutdinova \\ Dr.Professor, Department of foreign languages, Institute of International Relatons \\ Kazan Federal University, Russia \\ ORCID: http://orcid.org/0000-0001-7872-7507

\section{Lilia Ernstevna Ilicova} \\ Associate Professor and Deputy Director at Institute of International Relations of Kazan (Volga \\ Region) Federal University, Russia \\ ORCID: http://orcid.org/0000-0002-9739-5007
}

Received 08-12-20 Revised 09-30-20

Accepted 10-13-20 On line 01-12-21

*Correspondence

Email: florans955@mail.ru
Cite as:

Mukhametzyanova, F.G., Krasnoshchechenko, I.P., Fakhrutdinova, A.V., Ilicova, L.E. (2021). Moral and Spiritual Self-Improvement of Russian Youth in the Context of Religious and Cultural Awareness. Propósitos y Representaciones, 9 (SPE1), e833. Doi: http://dx.doi.org/10.20511/pyr2021.v9nSPE1.e833 


\section{Summary}

In the research the relation to a symbol of the icon of Kazan Mother of God is considered through the structure of identity of group of modern Cristian youth. Today the religiousness, religious belief is a psychological phenomenon focusing the person on a way of moral and spiritual self-improvement. The relation of citizens to Russian Cristian Church remains contradictory, especially at youth. In this regard the research of the relation to a unique historical and cultural and spiritual symbol of the Kazan icon of the Mother of God is perspective. It is one of the brightest and deepest Cristian symbols it content. History of the Kazan icon of the Mother of God is inseparably linked with the history of Russia. The purpose of this article is to present the results of the research aimed in the identification of the relation to a symbol of the Kazan icon of the Mother of God of modern Cristian youth in the context of interrelation of its confessional identity and religious and cultural awareness. Results of an empirical research allows to establish that, despite growth of religious interest in a symbol of an icon of Kazan Mother of God at young people the low level of knowledge, not formation of ideas of the historic facts connected with this icon is observed. The image of an icon and its historical context have the invaluable potential for spiritual and moral education of the Russian youth.

Keywords: Moral and spiritual self-improvement, youth, icon of Kazan Mother of God, religious and cultural awareness, Christianity.

\section{Resumen}

En la investigación se considera la relación con un símbolo del icono de la Madre de Dios de Kazán a través de la estructura de identidad del grupo de jóvenes cristianos modernos. Hoy la religiosidad, la creencia religiosa es un fenómeno psicológico que enfoca a la persona en un camino de superación moral y espiritual. La relación de los ciudadanos con la Iglesia Cristiana Rusa sigue siendo contradictoria, especialmente en la juventud. En este sentido, la investigación de la relación con un símbolo histórico, cultural y espiritual único del icono de Kazán de la Madre de Dios es la perspectiva. Es uno de los símbolos cristianos más brillantes y profundos que contiene. La historia del icono de Kazán de la Madre de Dios está indisolublemente ligada a la historia de Rusia. El propósito de este artículo es presentar los resultados de la investigación encaminada a la identificación de la relación con un símbolo del icono de Kazán de la Madre de Dios de la juventud cristiana moderna en el contexto de la interrelación de su identidad confesional y conciencia religiosa y cultural. . Los resultados de la investigación empírica permiten establecer que, a pesar del crecimiento del interés religioso en el símbolo del icono de la Madre de Dios de Kazán a los jóvenes se observa el nivel bajo del conocimiento, no la formación de las ideas de los hechos históricos vinculados a este icono. La imagen de un icono y su contexto histórico tienen un potencial invaluable para la educación espiritual y moral de la juventud rusa.

Palabras clave: superación moral y espiritual, juventud, icono de la Madre de Dios de Kazán, conciencia religiosa y cultural, cristianismo.

\section{Introduction}

In modern Russian society processes of liberalization, disintegration, consumer orientation, spiritual degradation and washing out of moral guidelines and foundations still presents. The tendency of increase of interest in religion, to religious symbols, to shrines and ceremonies as to instruments of maintaining the Russian identity is observed. It as opposition to destructive trends of globalization.

The celebration in 2018 of the 1030 anniversary from the moment of the Christianization of Kievan Rus' became a serious reason for judgment of a role of Christianity in the history and present of Russia. Consequences of adoption of the Christianity which transformed culture, consciousness of citizens of the Russia is highly appreciated not only by heads of the Russian orthodox Church, but also heads of modern Russia and the Russian scientists (Bratus, 2000, Granovskaya, 2004). In recent years domestic philosophers and psychologists began to address 
actively phenomena of religion, Cristianity, opening the value of religious life for the person (Zenko, 2009). The years which passed from the moment of the celebration of a 1000 anniversary of adoption of Christianity in Russia were followed not only by restoration of temples across all territory of Russia, but also strengthening of influence of Orthodoxy on consciousness of people in Post-Soviet society, on overcoming disintegration and strengthening of the Russian society (Lossovsky, 2014). According to results of sociological polls of the population, the vast majority of Russians call themselves orthodox Christians (Miklyaeva, Rumjantseva, 2008). At the same time the relation to Russian Cristian Church remains contradictory, and at a part of citizens alerted, especially among youth (Mokhailov, 2005).

In this regard the research of the youth relation to a unique historical and cultural and spiritual symbol of the Kazan icon of the Mother of God is perspective. It is one of the brightest and deepest Cristian symbols in this content. History of the Kazan icon of the Mother of God is inseparably linked with the history of Russia, and in consciousness of the believing person this symbol is connected with the Prototype, Blessed Virgin's identity of Maria (Florensky, 2008). In our plans carrying out a research of the relation to a symbol of the Kazan icon of the Mother of God of different social and demographic groups of society. These groups are allocated on the basis of set of characteristics, features of a social status and are caused by various socially psychological properties which are defined by structure of identity of individuals, etc.

The term "identity" in the status of a scientific concept into psychology was entered by E. Erikson (Erikson,1996). According to Eriksson "identity" is some condition of selfidentification, it is the internal continuity and identity of the personality existing in the context of continuous personal development and performing adaptation functions. The identity, at the same time, is the dynamic characteristic, which changes throughout all life of man (Erikson,1996).

In modern psychology "identity" is defined as a feeling of identity and integrity, property of mentality of the person and expresses in how one represents the belonging to various social, economic, national, professional, language, political, religious, racial and other groups, or in identification this or that person as the embodiment of properties inherent in these groups (Religion in Russia https://ru.wikipedia.org/wiki/, Khairutdinov, Mukhametsanova, 2017). Authors allocate different types of identity - personal (awareness of the uniqueness, originality of those lines which form it) and social (understanding of as member of a certain social group on certain signs) proceeding from what it is accepted to allocate ethno-cultural, confessional, gender and age, professional, political, spiritual and so forth (Mefodeva, Fakhrutdinova, Ukhimenko,2017).

In structure of identity as a phenomenon, belonging to consciousness and consciousness, traditionally allocate the following components:

1) cognitive - feeling by the subject of the belonging to a group (subgroup) and interactive communication within it, perception of oneself and others according to characteristics of significant group;

2) affective, motivationally-valuable - experience of feelings by the subject of communication within the group and assessment of positivity of this communication, experience of the compliance to the group and to the events happening with him;

3) behavioral - rather steady reproduction of characteristics, significant for group by the subject in the actions and acts, and also ones' behavior, in compliance with norms and expectations of the group.

\section{Methods}

The research is based on the following principles: systematization, objectivity, identity. Groups of methods of a research: theoretical - the theoretiko-methodological analysis of scientific and theological literature on a research problem are applied. 
Empirical - observation, a conversation, a method of expert assessment, questioning by a technique "Who I am?" (M. Kuhn).

\section{Analytical - content analysis}

According to the stated provisions we conducted an empirical research of content of identity of orthodox youth and its relation to a symbol of an icon of Kazan Mother of God by means of questioning and a technique "Who I am?" by M. Kong. The developed questionnaire included the following questions: 1. Do you consider yourself the believing person? 2. Whether Cristianity i for you is true religion? 3. Are you familiar with the history of appropriation of an icon of Kazan Mother of God? 4. If yes, call the year and / a historical context of an icon appropriation. 5. Do you know the historic facts connected with an icon of Kazan Mother of God? 6. Do you believe that in 2011 the patriarch Kirill transferred the replica of the icon of the Kazan Mother of God with a spiritual mission to the International Space Station? 7. Can you list days of special honoring of an icon of Kazan Mother of God? 8. Who wrote "Legends" on the Kazan icon of the Mother of God in 1594? 9. Why the icon of the Kazan Mother of God became a symbol of the Russian victories? 10. Whether the original of an icon of Kazan Mother of God exists now? 11.r Is the icon of the Kazan Mother of God especially esteemed for you? 12. If yes, what affected your attitude towards it? 13. You were in the places connected with an icon of Kazan Mother of God? 14. If yes, where? 15. Whether there is in your house an icon of Kazan Mother of God? 16. Whether you addressed an image of Kazan Mother of God in difficult situations? 17. Have you ever felt the real help in your life on prayers to the icon of Kazan Mother of God? 18. Do you visit temples in days of celebration of the Kazan icon of the Mother of God? 19. How do you consider, lately in Russia the number of the believing people reading the icon of Kazan Mother of God increased? 20. If yes, why? M. Kong's technique focused participants of a research on the wording of answers to the question "Who Am I?" (the record opportunity up to 10 definitions was given).

60 male respondents aged from 17 up to 26 years, on 30 people freshman and those who completed the first year of the Kaluga theological seminary participated in the conducted research.

\section{Results and Discussion}

Let's present some results, having reflected answers to the most important questions according to article purposes: "1. Do you consider yourself the believing person?", "5. Do you know the historic facts connected with an icon of Kazan Mother of God?", "7. Can you list days of special honoring of an icon of Kazan Mother of God?".

At data processing of the research is to define the main structural components concerning the relation to a symbol of an icon of Kazan Mother of God were defined: 1) the cognitive, expressing level of awareness on a symbol of the Kazan icon of the Mother of God connected with knowledge of the basic facts, concepts and their understanding; 2) the affective and motivational and estimated, reflecting personally significant motives, the relation to an icon symbol; 3) a behavioral component - characteristics of participation in the religious practices, holidays connected with an icon, the references which are markers to confessional social group "Orthodox Christians the Christian"..

First of all, we were interested in results of correlation by respondents of with social group of "orthodox Christians" and feature of awareness on a symbol of the Kazan icon of the Mother of God.

In answers to the question "Whether You Consider Yourself the Believing Person?" - the following data were obtained: $77 \%$ of examinees define themselves as believers, refrained from the answer or just did not answer $23 \%$ of examinees. 
Analysis of answers to a question: "Do you know the historic facts connected with an icon of Kazan Mother of God" - showed that only 37\% of examinees know historic facts about the Kazan icon of the Mother of God. 63\% of respondents are not informed on the matter of the fact of its acquaintance and of historic facts connected with the Kazan icon of the Mother of God, even in situation that during training in comprehensive school, this information is given. Besides, this icon is especially esteemed among Christians, most likely have an opportunity to participate in the ceremonies devoted to the events connected with the Icon. The received results give the ground for a conclusion that the cognitive component of spiritual identity of the examined group of youth is characterized by substantial deficiency.

Answering the question "Whether the icon of Kazan Mother of God is especially esteemed for you?", $80 \%$ of examinees answered positively, $20 \%$ answered negatively or refrained from the answer. This result demonstrates that the majority of interviewed admits the fact of the importance of a symbol of the Kazan icon of the Mother of God in the life (an emotional, motivationally-valuable component).

Answers to the question "Do you address the image of Kazan Mother of God in difficult situations?" show that $65 \%$ of respondents of the studied group at least once in life asked for the help in front of this icon. This, in-turn demonstrates rather steady reproduction by young people significant characteristics of group of orthodox community (a behavioral component).

By means of M. Kong's technique "Who you are?" we received confirmation to the fact that not all respondents understand essential meaning of their definition identity as "an Orthodox Christian" and "believer". Only 23\% of examinees noted in the identity as an Orthodox Christians, $77 \%$ did not specify any of these or relevant qualities. From here a conclusion that at most of the interviewed young people the confessional consciousness and confessional self-relation are insufficiently defined and created as at subjects of identity.

\section{Conclusions}

Thus, the Kazan icon of the Mother of God is one of the brightest and deep Cristiansymbols on the contents connected with the Prototype, Blessed Virgin's identity of Maria which history is a part of history of Russia. The image of the icon and its historical context have the invaluable potential for spiritual and moral education of the Russian youth, both in general education, and spiritual educational institutions which in the changed conditions of the present society is undervalued.

\section{Acknowledgements}

The work is performed according to the Russian Government Program of Competitive Growth of Kazan Federal University

\section{References}

Bratus, B.S. (2000), Russian, Soviet modern Russian Psychology: konspectivf view. M.: Flinta, $85 \mathrm{p}$.

Erikson, E. (1996), Identity: and Crisis. M.: Progress, 344 p.

Florensky, P. (2008), Iconostasis. M. : Eskimo, 76 p.

Granovskaya, R.M. (2004), Psychology of belief. S.Pb.: Rech, 373 p.

Khairutdinov R.R, Mukhametsanova F.G, Korjova E.Y., (2017), Subject-Object orientations for students with different learning profiles//European Research Studies Journal Vol.20, Is.. - P.369-376.

Lossovsky, V.N. (2014), Idea of Icons. M.: Trinity Humanitarian University:Eskimo:336 p. 
Mefodeva M. A., Fakhrutdinova A. V., Ukhimenko A. N. (2017), Historical perspectives of spiritual and moral education in India //Man in India. Vol.97, Is.8. - P.71-77.

Miklyaeva, A.V., Rumjantseva, P.V. (2008) Social identity of an individual: content, structure, mechanisms of formation. S.Pb, $118 \mathrm{p}$.

Mokhailov, U.P. (2005), Three words in psychology. S.Pb: Russkaya symphony 280 p.

Zenko, U.M. (2009), Psychology of religion. S.Pb.: Rech, 552 p. 